\title{
Trace elements determination in edible seaweeds by an optimized and validated ICP-MS method
}

\author{
S. Ródenas de la Rocha ${ }^{\text {a }}$, F.J. Sánchez-Muniz ${ }^{\text {b,* }}$, M. Gómez-Juaristi ${ }^{c}$, M.T. Larrea Marín ${ }^{\mathrm{d}}$ \\ a Departamento de Química Analítica, Facultad de Farmacia, Universidad Complutense, 28040 Madrid, Spain \\ ${ }^{\mathrm{b}}$ Departamento de Nutrición, Facultad de Farmacia, Universidad Complutense, 28040 Madrid, Spain \\ ${ }^{\text {c } C e n t r o ~ d e ~ E s p e c t r o m e t r i ́ a ~ A t o ́ m i c a . ~ U n i v e r s i d a d ~ C o m p l u t e n s e, ~} 28040$ Madrid, Spain \\ ${ }^{\mathrm{d}}$ Centro Nacional de Investigaciones Metalúrgicas (C.S.I.C). Avenida Gregorio del Amo, 8. 28040 Madrid, Spain
}

\section{A R T I C L E I N F O}

\section{Article history:}

Received 13 February 2008

Received in revised form 9 October 2008

Accepted 30 October 2008

\section{Keywords:}

Laminaria spp.

Porphyra spp.

Inductively coupled plasma mass

spectrometry

Seaweeds

Method validation

Microwave digestion

Minerals

Trace elements

Food analysis

Food composition

\begin{abstract}
A B S T R A C T
An optimized and validated inductively coupled plasma mass spectrometry (ICP-MS) method was used to analyze trace elements in seaweeds. Different volumes and rates of $\mathrm{HNO}_{3}$ and $\mathrm{H}_{2} \mathrm{O}_{2}$, digestion times, and microwave power levels were tested to ascertain the best conditions for sample digestion. Analytical mass and instrumental parameters were selected to assure accurate and precise determination of $\mathrm{As}, \mathrm{Cd}$, $\mathrm{Co}, \mathrm{Cr}, \mathrm{Mo}, \mathrm{Ni}, \mathrm{Pb}, \mathrm{Sb}$, Se, and $\mathrm{V}$ by ICP-MS. The method was optimized and validated using biological Certified Reference Materials. In addition, some samples of seaweeds (Porphyra and Laminaria) from France, Spain, Korea, and Japan were analyzed using the optimized method. Porphyra presented higher concentrations of most elements, except for As, than Laminaria. Seaweeds from Korea and Japan tended to display the highest concentrations of $\mathrm{Pb}$ and $\mathrm{Cd}$. In contrast, Spanish and French samples showed the highest levels of some micro-elements essential to human nutrition.
\end{abstract}

() 2009 Elsevier Inc. All rights reserved.

\section{Introduction}

Marine algae have been consumed traditionally in Asia but only occasionally in other parts of the world (Nisizawa et al., 1987). The increasing popularity of Oriental cuisine and macrobiotic diets in Western countries in recent years has increased the demand for these marine vegetables. From a nutritional point of view, seaweeds are characterized by high concentrations of fibre and minerals (Burtin, 2003; Bocanegra et al., 2003), low fat content and, in some cases, relatively high protein levels (Galland-Irmouli et al., 1999).

Seaweeds may contain a high mineral content, as their cell wall polysaccharides and proteins contain anionic carboxyl, sulphate and phosphate groups that are excellent binding sites for metal retention (Davis et al., 2003). This biochemical cell wall feature makes algal biomass one of the most promising biosorbents available for the removal of toxic heavy metals from industrial wastewaters (Volesky and Holan, 1995; Hardisson et al., 1996;

\footnotetext{
* Corresponding author. Tel.: +34 913 941828; fax: +34913941 810 .

E-mail address: frasan@farm.ucm.es (F.J. Sánchez-Muniz).
}

Storelli et al., 2001). However, the environmental characteristics of the water in which algae grow (salinity, turbidity, nutrient content, and heavy metal contamination) largely determine the mineral content they can absorb (Lozano et al., 2003; Riekie et al., 2006; Riget et al., 1997; Vasconcelos and Leal, 2001; Marinho-Soriano et al., 2006).

Under similar environmental conditions, mineral composition and content differ greatly between the different families, genera and species of macro-algae. Most of the limited information available on this subject comes from investigations carried out in Asia, as few systematic studies of seaweeds have been performed in Europe or North or South America (Mabeau and Fleurence, 1993; Rizvi and Shameel, 2001; Rupérez, 2002).

Research in this field is of great scientific importance as elements such as $\mathrm{As}, \mathrm{Cd}, \mathrm{Pb}$, and $\mathrm{Sb}$ may be present in seaweeds as a result of environmental contamination while others, including $\mathrm{Co}$, $\mathrm{Cr}, \mathrm{Mo}, \mathrm{Ni}, \mathrm{Se}$, and $\mathrm{V}$ are essential for humans. Little information on marine algae is currently available in Food Tables and more data would benefit future nutritional studies.

In order to quantify the mineral concentration in seaweed samples, numerous analytical procedures and techniques have been employed. Almela et al. (2006) used Graphite Furnace Atomic 
Absorption Spectrometry (GF-AAS) to determine As, $\mathrm{Cd}$, and $\mathrm{Pb}$ content in seaweeds. This technique is sensitive enough to detect elements present in very small quantities but, like all monoelemental techniques, it is slow and tedious for routine use, particularly when a vast number of elements and samples must be analyzed. Inductively Coupled Plasma Optical Emission Spectroscopy (ICP-OES) is a multi-elemental technique, but it is not sensitive enough to detect elements present at the ultra-trace level. Therefore, ICP-OES has been used only for macro-elemental analysis in seaweeds as Fe, Zn, Mg, Mn, and Ca (Munilla et al., 1995; Csikkel-Szolnoki et al., 2000; Domínguez-González et al., 2005).

Inductively Coupled Plasma Mass Spectrometry (ICP-MS), on the other hand, is a very sensitive and precise analytical technique that permits simultaneous determination of a wide range of trace and ultra-trace elements in various biological and pharmaceutical samples, with detection limits in the order of $\mathrm{ng}^{-\mathrm{g}^{-1}}$, similar to Graphite Furnace Atomic Absorption Spectroscopy (GF-AAS) (Le Lamer-Déchamps et al., 2003; Huang et al., 2006). However, polyatomic interferences resulting from the combination of matrix ions with Ar may affect this technique. To assure correct results, some of the interferences must be eliminated or controlled by microwave digestion at high temperatures while others have to be corrected using a mathematical equation.

ICP-MS has been validated for analysis of trace metals in plants (Leiterer et al., 1997). However ICP-MS is currently being used to detect metals in seaweeds (van Netten et al., 2000), and algae food products (Dawczynski et al., 2007), but no validation of this method for use in this biological material has yet been published. Thus, the first goal of this study was to optimize and validate the ICP-MS method to determine As, Cd, Pb, Sb, Co, Cr, Mo, Ni, Se, and V in seaweeds. The second goal was to apply the validated method to determine the trace element content of two edible classes of seaweeds (Porphyra and Laminaria) from two European locations (France and Spain) and two Asian locations (Korea and Japan) in order to enhance the nutritional knowledge of edible seaweeds.

\section{Materials and methods}

\subsection{Instrumentation}

A Conterm dry oven from EUROLAB LTD. (Barcelona, Spain) was employed to dry algae samples. Acid digestion of the seaweed samples was performed using a commercial high-pressure laboratory microwave oven (Milestone Ethos 1600 Microwave Labstation, Sorisole, Italy), operating at a frequency of $2450 \mathrm{~Hz}$, with an energy output of $900 \mathrm{~W}$. This microwave digestion system was equipped with ten $100 \mathrm{~mL}$ TFM (tetrafluoromethoxy) Teflon closed vessels, and temperature in the interior of the vessels can be monitored with the 300 Automatic Temperature Control Probe. Maximum operating temperature and pressure were $300{ }^{\circ} \mathrm{C}$ and 100 bar, respectively.

A VARIAN UltraMass Quadrupole Inductively Coupled Plasma Mass Spectrometer (Varian, Inc. Scientific Instruments Lake Forest, USA) was used for analytical determinations. Operating conditions of the ICP-MS for the analysis of the seaweed samples are shown in Table 1 . The instrumental parameters were optimized with a solution containing $10 \mu \mathrm{g} \cdot \mathrm{L}^{-1}$ of $\mathrm{Be}, \mathrm{Ba}, \mathrm{Ce}, \mathrm{Co}, \mathrm{In}, \mathrm{Pb}, \mathrm{Mg}$, Tl, and Th (Inorganic Ventures, Lakewood NJ, USA), and were employed for routine laboratory work.

\subsection{Trace element determination}

As, $\mathrm{Cd}, \mathrm{Cr}, \mathrm{Ni}$, and $\mathrm{V}$ were analyzed in concentrations of $\mu \mathrm{g} \cdot \mathrm{g}^{-1}$, whereas $\mathrm{Co}, \mathrm{Mo}, \mathrm{Pb}, \mathrm{Sb}$, and Se were analyzed in concentrations of ng. $\mathrm{g}^{-1}$. Five measurements were performed from each sample replicate.
Table 1

Operating conditions for ultra-mass ICP Mass Spectrometer.

\begin{tabular}{ll}
\hline Parameter & Value \\
\hline & Instrument \\
Spray chamber & Sturmann-Masters \\
Sample cone & Nickel, $1 \mathrm{~mm}$ orifice diameter \\
Skimmer cone & Nickel, $0.75 \mathrm{~mm}$ orifice diameter \\
Sample update rate & $1.0 \mathrm{~mL} / \mathrm{min}$ \\
Sample read delay & $35 \mathrm{~s}$ \\
& \\
Radiofrequency generator & Plasma conditions \\
Incident power & $40 \mathrm{MHz}$ \\
Plasma Ar flow rate & $1100 \mathrm{~W}$ \\
Nebulizer Ar flow rate & $16.5 \mathrm{~L} / \mathrm{min}$ \\
Auxiliary Ar flow rate & $0.87 \mathrm{~L} / \mathrm{min}$ \\
& $1.05 \mathrm{~L} / \mathrm{min}$ \\
Scanning mode & Peak Hopping \\
Resolution & High \\
Integration time & $900 \mathrm{~ms}$ \\
Dwell time & $300 \mathrm{~ms}$ \\
Number of readings per replicate & 1 \\
Number of replicate & 6 \\
\hline
\end{tabular}

\subsection{Reagents}

All closed vessels, polyethylene flasks and plastic containers were cleaned with $\mathrm{HNO}_{3}(65 \% \mathrm{w} / \mathrm{v}$, diluted $1 / 10$ with high-purity water) for $24 \mathrm{~h}$ and rinsed with high purity water. Subsequently, all material was dried at $50{ }^{\circ} \mathrm{C}$ and stored under clean-air conditions. All plastic containers, polyethylene flasks, pipette tips, PFA Teflon digestion vessels (Milestone SRL, Sorisole, Italy) and reagents that came into contact with the samples or standards were checked for contamination. All solvents and reagents were of the highest commercially available purity grade.

De-ionized water with a resistivity of $\geq 18 \mathrm{M} \Omega \cdot \mathrm{cm}^{-1}$ was obtained by means of a Milli-Q Plus pure water generating system from Millipore (Millipore Molsheim, France) and was employed to prepare all standard and sample solutions. Suprapur grade (Merck, Germany) $65 \% \mathrm{HNO}_{3}$ and $30 \% \mathrm{w} / \mathrm{v} \mathrm{H}_{2} \mathrm{O}_{2}$ were used for sample dissolution. Monoelemental, high-purity grade $1 \mathrm{~g} \cdot \mathrm{L}^{-1}$ stock solutions of As, Cd, Co, Cr, Ge, Mo, Ni, Pb, Re, Rh, Sb, Se, and V were purchased from Merck (Darmstadt, Germany). Plasma torch argon purity was higher than $99.999 \%$.

\subsection{Samples}

The following Certified Reference Materials (CRMs), which covered the range of the elements studied, were selected: BCR 279 (Sea lettuce, Ulva lactuca) for As, Cd, Cr, and Se from Community Bureau of Reference. NCS ZC78006 (Tea) for Co, and Sb from China National Analysis Center for Iron and Steel; NIST 1547 (Peach leaves) for $\mathrm{Ni}, \mathrm{Pb}, \mathrm{Mo}$, and $\mathrm{V}$ from National Institute of Standards \& Technology.

Two edible seaweed genera (Porphyra and Laminaria) of different origins were used. Seaweeds were harvested in geographical areas from Europe and Asia where traditionally they have been used for human consumption. Seaweeds from Japan (Koyo Food Ltd.: Kunga and Mitoku) and Korea (Wesbrag Ltd.: Yang-Tse) were purchased in a local market. Spanish seaweeds were supplied by Algas Atlánticas Algamar S.L. which were harvested in the Spanish northwest coast (Redondela, Galicia) and French samples were harvested in the France northwest coast (Brest, Brittany) by the authors in summer 2004 and they were dried up at low temperatures. Samples from Korea, Japan, and Spain were analyzed just as they were sold. Dried seaweeds were stored in air-tight containers, as they are hygroscopic until undergoing pre- 
analytic treatment. Six samples were analyzed from different manufacturing batch per each seaweed genera.

\subsection{Sample preparation and digestion}

Approximately $1 \mathrm{~g}$ of each dehydrated seaweed sample was rinsed for $3 \mathrm{~min}$ with $50 \mathrm{~mL}$ ultra-pure water to remove salts, and oven-dried at $55 \pm 5{ }^{\circ} \mathrm{C}$ for $24 \mathrm{~h}$. Subsequently, seaweed samples and CRMs were homogenized and ground in an agate ball mixer mill to reduce particle size to a maximum of $30 \mu \mathrm{m}$.

In order to optimize digestion, several modalities were assayed: (1) Different concentrations of $\mathrm{HNO}_{3}$ (from $2.5 \mathrm{~mL}$ to $5 \mathrm{~mL}$, in intervals of $0.5 \mathrm{~mL}$ ) and $\mathrm{H}_{2} \mathrm{O}_{2}$ (from $0 \mathrm{~mL}$ to $2.5 \mathrm{~mL}$, in intervals of $0.5 \mathrm{~mL}$ ) in $5 \mathrm{~mL}$ of acid mixture; (2) Various digestion times (from $5 \mathrm{~min}$ to $10 \mathrm{~min}$, in $1 \mathrm{~min}$ intervals); and (3) Several microwave oven powers (from $200 \mathrm{~W}$ to $650 \mathrm{~W}$, in intervals of $50 \mathrm{~W}$ ).

The method that used the lowest volume, power, and digestion time was considered the more convenient and finally selected. Two replicate solutions of each sample were prepared by microwaveassisted acid digestion. A set of digestion blanks was also prepared and subjected to the same microwave procedure. A $0.5000 \pm 0.0001 \mathrm{~g}$ portion of each dry seaweed and CRM was weighed and introduced into a high-pressure closed Teflon decomposition vessel. Then, $5 \mathrm{~mL}$ of previously optimized $\mathrm{HNO}_{3}$ and $\mathrm{H}_{2} \mathrm{O}_{2}$ mixture was carefully added to each sample and the vessels were gently shaken and sealed. A total of ten sub-samples were evenly spaced on the microwave turntable. Digested samples were transferred to a $50 \mathrm{~mL}$ volumetric flask and made up to volume with de-ionized water.

\subsection{Test solution and calibration}

A multi-elemental standard working solution with the elements to be analyzed at a concentration of $1 \mathrm{mg} \cdot \mathrm{L}^{-1}$ was prepared by step-wise dilutions of monoelemental stock solutions. This test solution contained $4.8 \mu \mathrm{g} \cdot \mathrm{L}^{-1}$ of Rh and $20 \mu \mathrm{g} \cdot \mathrm{L}^{-1}$ of Ge and Re that were used as internal standards to correct instrumental drift and possible matrix effects. All the solutions were $1 \%(\mathrm{~V} / \mathrm{V})$ in $\mathrm{HNO}_{3}$. For calibration, four multi-elemental solutions were prepared with the following concentrations: $0,3,10$ and $40 \mathrm{ng} \cdot \mathrm{mL}^{-1}$ for As; and $0,0.8,3.0$ and $10.0 \mathrm{ng} \cdot \mathrm{mL}^{-1}$ for $\mathrm{Cd}, \mathrm{Co}$, $\mathrm{Cr}, \mathrm{Mo}, \mathrm{Ni}, \mathrm{Pb}, \mathrm{Sb}, \mathrm{Se}$, and $\mathrm{V}$.

\subsection{Selection of analytical mass}

Elements with the highest isotopic abundance were selected as analytical mass, except in the case of $\mathrm{Ni}$ and Se (Table 2). These analytical masses are free from isobaric and polyatomic interferences; however, 75As and $51 \mathrm{~V}$ would be the only isotopes that high concentrations of chlorine ion could seriously interfere with. Thus, in the present study polyatomic interferences in 75As and 51 $\mathrm{V}$ were determined and controlled from chlorine $40 \mathrm{Ar} 35 \mathrm{Cl}$ and $35 \mathrm{Cl} 160$, respectively. Solutions with increasing $\mathrm{NaCl}$ concentra-

Table 2

Analytical mass selected.

\begin{tabular}{lc}
\hline Element & Mass $(\mathrm{m} / \mathrm{z})$ \\
\hline $\mathrm{As}$ & 75 \\
$\mathrm{Cd}$ & 114 \\
$\mathrm{Co}$ & 59 \\
$\mathrm{Cr}$ & 52 \\
$\mathrm{Mo}$ & 98 \\
$\mathrm{Ni}$ & 60 \\
$\mathrm{~Pb}$ & 206 \\
$\mathrm{Sb}$ & 121 \\
$\mathrm{Se}$ & 77 \\
$\mathrm{~V}$ & 51 \\
\hline
\end{tabular}

tions in high-purity water, covering the $0-3 \%$ range, with and without $3 \mu \mathrm{g} \cdot \mathrm{L}^{-1}$ of As and $\mathrm{V}$, respectively, were prepared.

\subsection{Validation studies}

The assays were validated with selected CRMs to assess withinand between-run accuracy and precision. For the within-run assessment, the accuracy and precision of the assays were examined in a single run, with six replicate samples. For the between-run assessment, each CRM was analyzed in six separate runs. Accuracy was defined as the percentage difference between the observed concentration and the expected value $(\% D)$. Precision was expressed as the percentage of the variation coefficient (\%CV).

Acceptance criteria for accuracy and precision, based on ICH (1996) rules, were as follows: the mean $\% D$ and $\% C V$ could not exceed $\pm 15 \%$; $75 \%$ of all samples had to be within $\pm 15 \%$ of expected concentrations; no more than one of the six samples within a given concentration could exceed $\pm 15 \%$ of their expected values.

Sensitivity of the determination of each chemical element at a specific isobaric mass, indicated in Table 2, was expressed by the slope of the linear regression equation $\left(\mathrm{cps} \cdot \mathrm{ng}^{-1} \cdot \mathrm{mL}\right)$. Linearity was assessed by the correlation coefficients of calibration curves and was considered acceptable when $r \geq 0$. 9995. Detection limits were calculated following the IUPAC rules (IUPAC, 1997; Thomsen et al., 2003 ) on the basis of the $3 \sigma$ criterion for ten replicate measurements of blank solutions subjected to the same treatment as the samples.

\subsection{Statistical analysis}

Two-way ANOVA (genus and country) was performed. When a significant genus-country interaction was found, the country effect was separately tested in Porphyra or Laminaria by post hoc analysis (Bonferroni test). The effect of genus on each mineral content was tested by unpaired Student's $t$-test. Results were considered significant at $p<0.05$. Statistical analyses were conducted using the SPSS version 15 statistical analysis packages (SPSS Inc., Chicago, IL, USA).

\section{Results and discussion}

\subsection{Optimization of the sample digestion procedure}

The optimized digestion method employed is shown in Table 3. The optimal proportion of $\mathrm{HNO}_{3}$ and $\mathrm{H}_{2} \mathrm{O}_{2}$ was 4.5:0.5 (V/V). The proposed digestion method led to a total and simultaneous dissolution of ten samples in only twenty-three min. Other additional advantages of this method include the small amount of reagent used $(5 \mathrm{~mL})$, which significantly reduces potential environmental contamination. Moreover, shorter digestion time is required in comparison to traditional methods as those proposed by Rodushkin et al. (1999), Wang et al. (2006), and Farías et al. (2002).

\subsection{Selection of analytical masses}

The analytical masses selected to perform determinations in the absence of isobaric interferences are indicated in Table 2. The

Table 3

Optimized program of sample digestion.

\begin{tabular}{llc}
\hline Step & Time $(\mathrm{min})$ & Power $(\mathrm{W})$ \\
\hline 1 & 2 & 250 \\
2 & 2 & 0 \\
3 & 6 & 250 \\
4 & 5 & 400 \\
5 & 2 & 0 \\
6 & 6 & 600 \\
\hline
\end{tabular}


Table 4

Within-run assay accuracy and precision for Certified Reference Materials.

\begin{tabular}{|c|c|c|c|c|c|}
\hline \multirow[t]{2}{*}{ Element } & \multirow[t]{2}{*}{ Certified Reference Material } & \multirow[t]{2}{*}{ Certified values $\left(\mu \mathrm{g} \cdot \mathrm{g}^{-1} \mathrm{DM}\right)$} & \multicolumn{3}{|l|}{ Within-run assay } \\
\hline & & & Found values $\left(\mu \mathrm{g} \cdot \mathrm{g}^{-1} \mathrm{DM}\right)$ & $\% D$ & $\% \mathrm{CV}$ \\
\hline As & BCR 279 Sea lettuce (Ulva lactuca) & $3.09 \pm 0.20$ & $3.26 \pm 0.18$ & +5.52 & 5.52 \\
\hline $\mathrm{Cd}$ & BCR 279 Sea lettuce (Ulva lactuca) & $0.274 \pm 0.022$ & $0.277 \pm 0.025$ & +1.12 & 9.02 \\
\hline Co & NCS ZC78006 Tea & $(0.20)$ & $0.19 \pm 0.02$ & -5.5 & 7.89 \\
\hline $\mathrm{Cr}$ & BCR 279 Sea lettuce (Ulva lactuca) & $(9.70-11.6)$ & $10.07 \pm 0.85$ & +3.82 & 8.44 \\
\hline $\mathrm{Ni}$ & NIST1547 Peach leaves & $0.69 \pm 0.09$ & $0.73 \pm 0.10$ & +5.55 & 7.28 \\
\hline Mo & NIST1547 Peach leaves & $0.060 \pm 0.008$ & $0.057 \pm 0.006$ & -5.00 & 10.52 \\
\hline $\mathrm{Pb}$ & NIST1547 Peach leaves & $0.87 \pm 0.03$ & $0.88 \pm 0.04$ & +1.15 & 9.32 \\
\hline $\mathrm{Sb}$ & NCS ZC78006 Tea & $0.037 \pm 0.003$ & $0.039 \pm 0.003$ & +5.40 & 7.69 \\
\hline $\mathrm{Se}$ & BCR 279 Sea lettuce (Ulva lactuca) & $0.593 \pm 0.032$ & $0.667 \pm 0.078$ & +12.50 & 11.69 \\
\hline V & NIST1547 Peach leaves & $0.37 \pm 0.03$ & $0.36 \pm 0.03$ & -2.70 & 6.94 \\
\hline
\end{tabular}

Results are mean \pm standard deviation of samples analyzed six times at the same assay. The value in () is for reference only, they are not certified values.

Table 5

Between-run assay accuracy and precision for Certified Reference Materials.

\begin{tabular}{|c|c|c|c|c|c|}
\hline \multirow[t]{2}{*}{ Element } & \multirow[t]{2}{*}{ Certified Reference Material } & \multirow[t]{2}{*}{ Certified values $\left(\mu \mathrm{g} \cdot \mathrm{g}^{-1} \mathrm{DM}\right)$} & \multicolumn{3}{|l|}{ Between-run assay } \\
\hline & & & Found values $\left(\mu g \cdot g^{-1} \mathrm{DM}\right)$ & $\% D$ & $\% \mathrm{CV}$ \\
\hline As & BCR 279 Sea lettuce (Ulva lactuca) & $3.09 \pm 0.20$ & $3.38 \pm 0.17$ & +.38 & 5.02 \\
\hline $\mathrm{Cd}$ & BCR 279 Sea lettuce (Ulva lactuca) & $0.274 \pm 0.022$ & $0.279 \pm 0.023$ & +1.82 & 8.24 \\
\hline Co & NCS ZC78006 Tea & $(0.20)$ & $0.19 \pm 0.02$ & -5.0 & 8.42 \\
\hline $\mathrm{Cr}$ & BCR 279 Sea lettuce (Ulva lactuca) & $(9.70-11.6)$ & $10.10 \pm 0.95$ & +4.12 & 9.40 \\
\hline $\mathrm{Ni}$ & NIST1547 Peach leaves & $7.61 \pm 0.48$ & $7.28 \pm 0.63$ & -4.33 & 8.65 \\
\hline Mo & NIST1547 Peach leaves & $0.060 \pm 0.008$ & $0.055 \pm 0.007$ & -8.33 & 12.73 \\
\hline $\mathrm{Pb}$ & NIST1547 Peach leaves & $1.06 \pm 0.10$ & $1.12 \pm 0.10$ & +5.66 & 8.92 \\
\hline $\mathrm{Sb}$ & NCS ZC78006 Tea & $0.037 \pm 0.003$ & $0.040 \pm 0.002$ & +8.12 & 5.0 \\
\hline Se & BCR 279 Sea lettuce (Ulva lactuca) & $0.593 \pm 0.032$ & $0.670 \pm 0.075$ & +12.98 & 11.19 \\
\hline V & NIST1547 Peach leaves & $0.37 \pm 0.03$ & $0.35 \pm 0.02$ & -5.40 & 6.85 \\
\hline
\end{tabular}

Results are mean \pm standard deviation of samples analyzed in six different assays. The value in () is for reference only, they are not certified values.

potential polyatomic spectral interference of $\mathrm{ArCl}$ species on 75As and $51 \mathrm{~V}$ affected by chlorine ion was not observed in the present study. The amount of chlorine ion in other types of marine plants should be measured before analyte determination, and only corrected by mathematical equations when this measure affects these analytical masses.

The proposed microwave digestion method avoided potential polyatomic interferences on $52 \mathrm{Cr}$ and $59 \mathrm{Co}$ isotopic mass by $40 \mathrm{Ar} 12 \mathrm{C}$ and $43 \mathrm{C} 16 \mathrm{O}$, respectively. No problems with isobaric interferences arose in the determination of $\mathrm{Cd}, \mathrm{Pb}, \mathrm{Sb}$, and Mo with the ICP-MS method. These findings coincide with those of Caroli et al. (1999). The 60Ni isotope was chosen for Ni determination, as its use avoids interferences with $23 \mathrm{Na} 35 \mathrm{Cl}$ or $58 \mathrm{Fe}$ when $58 \mathrm{Ni}$ is analyzed.

\subsection{Results of validation of methodology}

Within and between-run accuracy and precision of the assays are summarized in Tables 4 and 5 . The percentage difference between the observed concentration and the expected value $(\% D)$ was minimum for $\mathrm{Cd}$ and maximum for Se in both the within-run and between-run assays. The \% coefficient of variation was minimum for As and maximum for Se and Mo in both types of assays. In all cases, the observed values were within the acceptance criteria outlined above. Good agreement with certified concentrations in CRMs was found in the present study (Tables 4 and 5).

Sensitivities were maximum for V (15574.70 cps.ng $\left.{ }^{-1} \mathrm{~mL}\right)$ and minimum for Se (95.04 cps.ng ${ }^{-1} \mathrm{~mL}$ ). Based on their sensitivity, the elements studied can be ordered according to the following sequence: $\mathrm{V}>\mathrm{Cr}>\mathrm{Ni}>\mathrm{Co}>\mathrm{Mo}>\mathrm{Sb}>\mathrm{Cd}>\mathrm{As}>\mathrm{Pb}>\mathrm{Se}$. The correlation coefficients for the majority of the calibration curves were at least 0.998; thus, displaying good linear relationships throughout the concentration range studied. Consequently, the analytical masses shown in Table 2 were considered optimum for the proposed method.
Detection limits are indicated in Table 6. They were comparable with those obtained by other authors in similar samples (Harrington et al., 1999) and appropriate for application in the determination of seaweed mineral content.

\subsection{Trace elements in seaweeds}

The results of the elemental analysis of seaweed samples are summarized in Tables 7 and 8. With the exception of $\mathrm{Co}, \mathrm{Ni}$, and $\mathrm{Sb}$ values, mineral content of Porphyra (Rhodophyceae) and Laminaria (Phaeophyceae) differed significantly $(p<0.05)$. Struck et al. (1997); Phaneuf et al. (1999); Rupérez (2002) and van Netten et al. (2000) have also reported a wide variation in mineral concentration in different marine algae species, even when differences in environmental factors were minimized (Farías et al., 2002).

The order of element concentrations determined in this study for Porphyra was $\mathrm{As}>\mathrm{Cd}>\mathrm{V}>\mathrm{Ni}>\mathrm{Cr}>\mathrm{Pb}>\mathrm{Se}>\mathrm{Mo}>\mathrm{Co}>\mathrm{Sb}$, while that of Laminaria was $\mathrm{As}>\mathrm{V}>\mathrm{Cd}>\mathrm{Ni}>\mathrm{Cr}>\mathrm{Pb}>\mathrm{Se}>$ $\mathrm{Co}>\mathrm{Mo}>\mathrm{Sb}$. Porphyra contained higher concentrations of most of

Table 6

Limits of detection of elements.

\begin{tabular}{ll}
\hline Elements & Limits of detection $\left(\mu \mathrm{g} \cdot \mathrm{g}^{-1}\right)$ \\
\hline $\mathrm{As}$ & $1.33 \times 10^{-3}$ \\
$\mathrm{Cd}$ & $2.79 \times 10^{-4}$ \\
$\mathrm{Co}$ & $1.38 \times 10^{-4}$ \\
$\mathrm{Cr}$ & $4.36 \times 10^{-4}$ \\
$\mathrm{Mo}$ & $1.54 \times 10^{-4}$ \\
$\mathrm{Ni}$ & $1.32 \times 10^{-3}$ \\
$\mathrm{~Pb}$ & $1.74 \times 10^{-3}$ \\
$\mathrm{Sb}$ & $4.12 \times 10^{-4}$ \\
$\mathrm{Se}$ & $2.50 \times 10^{-2}$ \\
$\mathrm{~V}$ & $5.23 \times 10^{-5}$ \\
\hline
\end{tabular}


Table 7

Trace elements determined by ICP-MS in Porphyra and Laminaria from different locations.

\begin{tabular}{|c|c|c|c|c|}
\hline Element & Genus & Mean \pm SD & $p<0.05$ & $\begin{array}{l}\text { 95\% Confidence } \\
\text { interval }\end{array}$ \\
\hline Co $\left(n g \cdot g^{-1} \mathrm{DM}\right)$ & $\begin{array}{l}\text { Porphyra } \\
\text { Laminaria }\end{array}$ & $\begin{array}{l}182 \pm 58 \\
178 \pm 96\end{array}$ & NS & $\begin{array}{l}155-209 \\
133-223\end{array}$ \\
\hline Mo (ng.g $\left.{ }^{-1} \mathrm{DM}\right)$ & $\begin{array}{l}\text { Porphyra } \\
\text { Laminaria }\end{array}$ & $\begin{array}{l}438 \pm 368 \\
103 \pm 53\end{array}$ & $*$ & $\begin{array}{r}266-610 \\
78-127\end{array}$ \\
\hline $\mathrm{Pb}\left(\mathrm{ng} \cdot \mathrm{g}^{-1} \mathrm{DM}\right)$ & $\begin{array}{l}\text { Porphyra } \\
\text { Laminaria }\end{array}$ & $\begin{array}{l}513 \pm 212 \\
791 \pm 519\end{array}$ & * & $\begin{array}{l}414-612 \\
548-1034\end{array}$ \\
\hline $\mathrm{Sb}\left(\mathrm{ng} \cdot \mathrm{g}^{-1} \mathrm{DM}\right)$ & $\begin{array}{l}\text { Porphyra } \\
\text { Laminaria }\end{array}$ & $\begin{array}{l}30.5 \pm 24.9 \\
31.6 \pm 7.0\end{array}$ & NS & $\begin{array}{l}18.8-42.2 \\
28.3-34.8\end{array}$ \\
\hline Se (ng.g $\left.{ }^{-1} \mathrm{DM}\right)$ & $\begin{array}{l}\text { Porphyra } \\
\text { Laminaria }\end{array}$ & $\begin{array}{l}463 \pm 67 \\
334 \pm 151\end{array}$ & * & $\begin{array}{l}431-494 \\
263-405\end{array}$ \\
\hline As $\left(\mu g \cdot g^{-1} D M\right)$ & $\begin{array}{l}\text { Porphyra } \\
\text { Laminaria }\end{array}$ & $\begin{array}{c}7.3 \pm 2.3 \\
43.5 \pm 10.3\end{array}$ & * & $\begin{array}{c}6.2-8.3 \\
38.6-48.3\end{array}$ \\
\hline $\mathrm{Cd}\left(\mu \mathrm{g} \cdot \mathrm{g}^{-1} \mathrm{DM}\right)$ & $\begin{array}{l}\text { Porphyra } \\
\text { Laminaria }\end{array}$ & $\begin{array}{l}2.4 \pm 1.2 \\
1.0 \pm 1.1\end{array}$ & * & $\begin{array}{c}1.9-2.9 \\
0.48-1.55\end{array}$ \\
\hline $\mathrm{Cr}\left(\mu \mathrm{g} \cdot \mathrm{g}^{-1} \mathrm{DM}\right)$ & $\begin{array}{l}\text { Porphyra } \\
\text { Laminaria }\end{array}$ & $\begin{array}{l}1.0 \pm 0.2 \\
0.9 \pm 0.2\end{array}$ & * & $\begin{array}{l}0.91-1.07 \\
0.77-0.95\end{array}$ \\
\hline $\mathrm{Ni}\left(\mu \mathrm{g} \cdot \mathrm{g}^{-1} \mathrm{DM}\right)$ & $\begin{array}{l}\text { Porphyra } \\
\text { Laminaria }\end{array}$ & $\begin{array}{l}1.1 \pm 1.1 \\
1.0 \pm 0.2\end{array}$ & NS & $\begin{array}{l}0.62-1.61 \\
0.86-1.04\end{array}$ \\
\hline$V\left(\mu g \cdot g^{-1} D M\right)$ & $\begin{array}{l}\text { Porphyra } \\
\text { Laminaria }\end{array}$ & $\begin{array}{l}2.4 \pm 1.9 \\
1.3 \pm 1.1\end{array}$ & * & $\begin{array}{c}1.5-3.2 \\
0.78-1.83\end{array}$ \\
\hline
\end{tabular}

Values are Mean \pm SD of six samples. NS: Not significant.

$p<0.05$ significant differences for the same element.

the minerals analyzed than Laminaria, while the latter contained much higher levels of As (Table 7). Dawczynski et al. (2007) showed that in the Phaeophyceae mean contents of As were about ten times higher than in Rhodophyceae.

As content in Laminaria samples is in the same order than Laminaria analyzed by Almela et al. (2002) that was 47-53 $\mu \mathrm{g} \cdot \mathrm{g}^{-1}$ DM but higher than that analyzed by Dawczynski et al. (2007) $\left(8.42 \pm 2.26 \mu \mathrm{g} \cdot \mathrm{g}^{-1} \mathrm{DM}\right.$ in food products samples). In fact, the first author pointed out a relation in type of seaweed with As content: Phaeophyceae $>$ Rhodophyceae.
Differences in the biosorption of metals by seaweeds may be explained by differences in the amount and composition of polysaccharides in seaweed cell walls (Burtin, 2003; Davis et al., 2003). The principal components in cell walls of brown alga (e.g. Laminaria) are cellulose, fucoidan, alginic acids, and alginates (of which the most important are fucans and laminarans). Consequently, their main active groups are negatively charged functional ones, such as carboxyl and sulphate. Red seaweeds (e.g. Porphyra) also contain cellulose but their biosorption properties are characterized by their content in sulphated polysaccharides made of galactans (such as agar and carrageenans) and xylans (Loban and Harrison, 1994; Jimenez-Escrig and Sánchez-Muniz, 2000).

Other factors, including the environmental features of each region (water temperature, $\mathrm{pH}$ and salinity), may affect metal accumulation (Struck et al., 1997; Lodeiro et al., 2005; MarinhoSoriano et al., 2006). The relative abundance of a certain element in seawater and its bioavailability may also affect electrostatic adsorption (Sánchez Rodríguez et al., 2001). Moreover, presence of others metals in the seawater can also modulate seaweed metal content. Sánchez Rodríguez et al. (2001) found a linear correlation between some pairs of elements. Other factors that have an important bearing on the concentrations of some metals in seaweeds include the seasonality of the sampling (Hou and Yan, 1998; Vasconcelos and Leal, 2001) and the age of the fronds, which become more retentive over time (Farías et al., 2002).

In the present study, Asian tested seaweeds presented higher levels of Pb and Cd (Pb: 623-1265 ng.g ${ }^{-1} \mathrm{DM}$; Cd: $1.6-3.1 \mathrm{ng} \cdot \mathrm{g}^{-1}$ DM, data not shown) than their European counterparts ( $\mathrm{Pb}: 317-$ $403 \mathrm{ng} \cdot \mathrm{g}^{-1} \mathrm{DM}, \mathrm{Cd}: 0.40-1.70 \mathrm{ng} \cdot \mathrm{g}^{-1} \mathrm{DM}$, data not shown), possibly reflecting different levels of environmental pollution. Pollution reports from many parts of the world including China (Almela et al., 2006), India (Rao et al., 2007), Korea (Munilla et al., 1995; Almela et al., 2006), Japan (Munilla et al., 1995; van Netten et al., 2000; Almela et al., 2006), Spain (Almela et al., 2006; Moreda-Piñeiro et al., 2007), Italy (Caliceti et al., 2002), Argentina (Pérez et al., 2007) and Canada (Sharp et al., 1988; Phaneuf et al., 1999; van Netten et al., 2000) offer data regarding Pb levels in seaweeds. Concentrations of this element vary widely between areas studied, but most authors report the highest levels in Japan and Korea.

Table 8

Results of analysis for trace and ultratrace elements from Porphyra and Laminaria from different European and Asian countries.

\begin{tabular}{|c|c|c|c|c|c|c|c|c|}
\hline Element & Genus & France & Spain & Korea & Japan & Genus & Country & Interaction \\
\hline \multirow[t]{2}{*}{ Co (ng.g $\left.{ }^{-1} \mathrm{DM}\right)$} & Porphyra & $256 \pm 31+^{c}$ & $207 \pm 15^{+b}$ & $142 \pm 23+^{a}$ & $112 \pm 15^{+^{a}}$ & NS & *** & $* * *$ \\
\hline & Laminaria & $72.8 \pm 8.7^{a}$ & $99.8 \pm 8.8^{b}$ & $253 \pm 14^{c}$ & $287 \pm 8^{d}$ & & & \\
\hline \multirow[t]{2}{*}{ Mo (ng.g $\left.{ }^{-1} \mathrm{DM}\right)$} & Porphyra & $1030 \pm 40+^{c}$ & $408 \pm 13+^{b}$ & $174 \pm 48^{\mathrm{a}}$ & $140 \pm 17+^{a}$ & $* * *$ & ${ }^{* * *}$ & $* * *$ \\
\hline & Laminaria & $48.4 \pm 4.4^{\mathrm{a}}$ & $72.8 \pm 3.9^{\mathrm{b}}$ & $183 \pm 8^{d}$ & $106 \pm 10^{c}$ & & & \\
\hline \multirow[t]{2}{*}{$\mathrm{Pb}\left(\mathrm{ng} \cdot \mathrm{g}^{-1} \mathrm{DM}\right)$} & Porphyra & $312 \pm 22+^{a}$ & $493 \pm 14+^{c}$ & $397 \pm 32+^{b}$ & $848 \pm 53+^{d}$ & $* * *$ & ${ }^{* * *}$ & $* * *$ \\
\hline & Laminaria & $249 \pm 21^{\mathrm{a}}$ & $385 \pm 14^{\mathrm{b}}$ & $1488 \pm 131^{d}$ & $1042 \pm 51^{\mathrm{c}}$ & & & \\
\hline \multirow[t]{2}{*}{$\mathrm{Sb}\left(\mathrm{ng} \cdot \mathrm{g}^{-1} \mathrm{DM}\right)$} & Porphyra & $23.0 \pm 5.7^{\mathrm{b}}$ & $17.0 \pm 5.4+^{\mathrm{b}}$ & $11.0 \pm 4.4+^{\mathrm{a}}$ & $71.00 \pm 6.52+^{c}$ & NS & ${ }^{* * *}$ & $* * *$ \\
\hline & Laminaria & $29.0 \pm 2.6^{\mathrm{b}}$ & $29.2 \pm 4.1^{\mathrm{b}}$ & $40.8 \pm 7.5^{c}$ & $27.20 \pm 2.77^{\mathrm{a}}$ & & & \\
\hline \multirow[t]{2}{*}{ Se $\left(n g \cdot g^{-1} D M\right)$} & Porphyra & $502 \pm 22+^{c}$ & $536 \pm 22+^{c}$ & $375 \pm 24+^{a}$ & $438 \pm 32+^{b}$ & $* * *$ & ${ }^{* * *}$ & $* * *$ \\
\hline & Laminaria & $575 \pm 24^{\mathrm{d}}$ & $231 \pm 13^{b}$ & $201 \pm 8^{a}$ & $328 \pm 9^{c}$ & & & \\
\hline \multirow[t]{2}{*}{ As $\left(\mu g \cdot g^{-1} D M\right)$} & Porphyra & $4.25 \pm 0.13+^{a}$ & $8.77 \pm 1.36+^{c}$ & $6.28 \pm 0.19+^{b}$ & $9.70 \pm 1.20+^{c}$ & $* * *$ & $* * *$ & $* * *$ \\
\hline & Laminaria & $53.1 \pm 2.9^{c}$ & $30.1 \pm 7.0^{\mathrm{a}}$ & $40.02 \pm 3.82^{b}$ & $50.7 \pm 3.8^{c}$ & & & \\
\hline \multirow[t]{2}{*}{$C d\left(\mu g \cdot g^{-1} D M\right)$} & Porphyra & $2.88 \pm 0.13+^{b}$ & $0.46 \pm 0.06^{\mathrm{a}}$ & $3.07 \pm 0.07+^{c}$ & $3.18 \pm 0.08+^{c}$ & $* * *$ & ${ }^{* * *}$ & $* * *$ \\
\hline & Laminaria & $0.46 \pm 0.08^{\mathrm{b}}$ & $0.35 \pm 0.10^{\mathrm{b}}$ & $0.31 \pm 0.07^{\mathrm{a}}$ & $2.95 \pm 0.19^{c}$ & & & \\
\hline \multirow[t]{2}{*}{$\mathrm{Cr}\left(\mu \mathrm{g} \cdot \mathrm{g}^{-1} \mathrm{DM}\right)$} & Porphyra & $0.81 \pm 0.10+^{a}$ & $1.19 \pm 0.13+^{b}$ & $0.95 \pm 0.12^{\mathrm{a}}$ & $1.04 \pm 0.11+^{\mathrm{ab}}$ & ${ }^{* * *}$ & ${ }^{* *}$ & $* * *$ \\
\hline & Laminaria & $0.98 \pm 0.06^{\mathrm{b}}$ & $0.65 \pm 0.04^{\mathrm{a}}$ & $1.09 \pm 0.06^{\mathrm{c}}$ & $0.73 \pm 0.04^{\mathrm{a}}$ & & & \\
\hline \multirow[t]{2}{*}{$\mathrm{Ni}\left(\mu \mathrm{g} \cdot \mathrm{g}^{-1} \mathrm{DM}\right)$} & Porphyra & $1.22 \pm 0.20+^{b}$ & $2.76 \pm 0.16+^{c}$ & $0.27 \pm 0.07+^{a}$ & $0.23 \pm 0.044^{a}$ & $* * *$ & ${ }^{* * *}$ & $* * *$ \\
\hline & Laminaria & $0.65 \pm 0.04^{\mathrm{a}}$ & $1.01 \pm 0.074^{\mathrm{b}}$ & $1.14 \pm 0.04^{\mathrm{c}}$ & $1.00 \pm 0.07^{\mathrm{b}}$ & & & \\
\hline \multirow[t]{2}{*}{$V\left(\mu g \cdot g^{-1} D M\right)$} & Porphyra & $5.06 \pm 0.13+^{c}$ & $3.05 \pm 0.16+^{b}$ & $0.66 \pm 0.11+^{a}$ & $0.70 \pm 0.08^{a}$ & $* * *$ & ${ }^{* * *}$ & $* * *$ \\
\hline & Laminaria & $0.76 \pm 0.03^{a}$ & $0.67 \pm 0.02^{\mathrm{a}}$ & $3.2 \pm 0.16^{\mathrm{b}}$ & $0.60 \pm 0.07^{\mathrm{a}}$ & & & \\
\hline
\end{tabular}

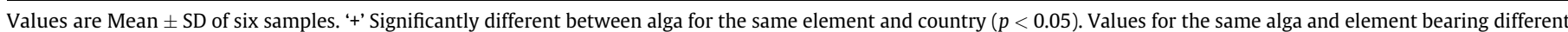
letters ( $\mathrm{a}, \mathrm{b}, \mathrm{c}$ and $\mathrm{d}$ ) are significantly different (at least $p<0.05)$. NS $=$ Not significant.

${ }_{* * * *}^{*} p<0.01$. 
Cd levels in the present study were higher in Porphyra than in Laminaria (Table 7). It agrees with Dawczynski et al. (2007) (Porphyra $1.13 \pm 1.06 \mu \mathrm{g} \cdot \mathrm{g}^{-1} \mathrm{DM}$ and Laminaria $0.59 \pm 0.21 \mu \mathrm{g} \cdot \mathrm{g}^{-1}$ DM). On the other hand, results presented in Table 8 indicate that the country of origin represents a significant cause for variation $(p<0.001)$ in the concentrations of the elements studied. Thus, the highest Cd levels were found in Japanese Porphyra samples. Almela et al. (2006) found a wide range of concentrations (0.019$3.09 \mu \mathrm{g} \cdot \mathrm{g}^{-1}$ ) for Cd in Porphyra from different origins, including Korea and Japan. van Netten et al. (2000), however, reported lower Cd levels in Porphyra from Japan $\left(0.27\right.$ and $\left.0.83 \mu \mathrm{g} \cdot \mathrm{g}^{-1}\right)$.

In the present study, $\mathrm{Cr}$ values of the two algae genera assayed were significantly different, except in the case of the Korean seaweeds. $\mathrm{Cr}$ in studied Porphyra is present in a narrow range from 0.81 to $1.19 \mu \mathrm{g} \cdot \mathrm{g}^{-1} \mathrm{DM}$ and those were similar to reporting by Moreda-Piñeiro et al. (2007) in seaweeds from the Galician Coast $\left(1.31 \pm 0.1 \mu \mathrm{g} \cdot \mathrm{g}^{-1} \mathrm{DM}\right)$ and Caliceti et al. (2002) in Venice lagoon $\left(0.5-1.0 \mu \mathrm{g} \cdot \mathrm{g}^{-1} \mathrm{DM}\right)$, and van Netten et al. (2000) from Japanese samples $\left(<0.5-2.0 \mu \mathrm{g} \cdot \mathrm{g}^{-1} \mathrm{DM}\right)$. Values in Laminaria agree with those of van Netten et al. (2000) $\left(<0.5-1 \mu \mathrm{g} \cdot \mathrm{g}^{-1} \mathrm{DM}\right)$ from Japan and Phaneuf et al. (1999) $\left(1.47 \pm 0.94 \mu \mathrm{g} \cdot \mathrm{g}^{-1} \mathrm{DM}\right)$ from Canada.

Very high levels of Mo were found in European Porphyra samples, especially those from France. Similar Mo content was found by Pérez et al. (2007) in Porphyra from Argentina (1.18$\left.1.99 \mu \mathrm{g} \cdot \mathrm{g}^{-1} \mathrm{DM}\right)$. Concentrations of elements (Co, Ni, and V) in human food are of great interest, due to their bioactivity and role in human metabolism. The highest levels of $\mathrm{Co}, \mathrm{Ni}$, and $\mathrm{V}$ in the present study were also found in European Porphyra (232 \pm 34 ng. $\mathrm{g}^{-1} \mathrm{DM}, 2.0 \pm 0.8 \mu \mathrm{g} \cdot \mathrm{g}^{-1} \mathrm{DM}, 4.1 \pm 1.1 \mu \mathrm{g} \cdot \mathrm{g}^{-1} \mathrm{DM}$, respectively).

Significant differences in $\mathrm{Ni}$ levels between seaweed genera from each location were found (Table 8). Ni levels in Porphyra concur with those reported in Porphyra columbina (Pérez et al., 2007) (0.74-1.51 $\left.\mu \mathrm{g} \cdot \mathrm{g}^{-1} \mathrm{DM}\right)$, are slightly higher than those of Porphyra vietnamensis (Rao et al., 2007) $\left(0.13 \pm 0.01 \mu \mathrm{g} \cdot \mathrm{g}^{-1} \mathrm{DM}\right)$ but much lower that those reported in Japanese Porphyra tenera (van Netten et al., 2000) (10.17 $\left.\mu \mathrm{g} \cdot \mathrm{g}^{-1} \mathrm{DM}\right)$. In the current study the highest Laminaria Ni levels were found in samples from Korea and there were no differences in samples from Spain and Japan. van Netten et al. (2000) found a wider range $\left(<0.05-1.31 \mu \mathrm{g} \cdot \mathrm{g}^{-1} \mathrm{DM}\right)$ in Japanese samples.

Except in Japanese algae, $\mathrm{V}$ levels differed significantly between Porphyra and Laminaria. van Netten et al. (2000) precisely in Japanese samples reported high differences between this seaweed genera (Porphyra 1.53-3.96 $\mu \mathrm{g} \cdot \mathrm{g}^{-1}$ DM and Laminaria 0.43$\left.1.17 \mu \mathrm{g} \cdot \mathrm{g}^{-1} \mathrm{DM}\right)$. In this work, much higher content of this element for Porphyra samples was observed in European locations $\left(4.1 \pm 1.1 \mu \mathrm{g} \cdot \mathrm{g}^{-1} \mathrm{DM}\right.$, data not shown)) than in Asian locations $\left(0.7 \pm 0.1 \mu \mathrm{g} \cdot \mathrm{g}^{-1} \mathrm{DM}\right.$, data not shown). Those agree with Farías et al. (2007) in Porphyra samples from Argentine coast (3.52-4.54 $\mu \mathrm{g} \cdot \mathrm{g}^{-1}$ DM) but it does not agree with van Netten et al. (2000).

Present Co data coincide with values reported by MoredaPiñeiro et al. (2007) from Galicia (Spain) (Porphyra $310 \pm 10 \mathrm{ng} \cdot \mathrm{g}^{-1}$ $\mathrm{DM}$ and Laminaria $\left.<200 \mathrm{ng} \cdot \mathrm{g}^{-1} \mathrm{DM}\right)$, but were lower than the concentrations observed by van Netten et al. (2000) from Japan (Porphyra 470-566 ng.g ${ }^{-1}$ DM and Laminaria 84-449 ng.g ${ }^{-1} \mathrm{DM}$ ) and Pérez et al. (2007) from Argentina (Porphyra 380-550 ng.g ${ }^{-1}$ DM). It has been observed that Co levels were similar in both studied genera

No previously published information is available for $\mathrm{Sb}$ concentrations in the two genera of algae tested in the present study. We observed similar Sb levels in Porphyra and Laminaria, and the highest concentrations were found in the Japanese and Korean samples. Hou and Yan (1998) found $0.121 \mathrm{ng} \cdot \mathrm{g}^{-1} \mathrm{Sb}$ in Chinese Pheaeophyceae and $0.141 \mathrm{ng} \cdot \mathrm{g}^{-1}$ Chinese, Rhodophyceae.

Se content of seaweeds in the present study was similar to that reported by van Netten et al. (2000) (Porphyra 200 ng.g ${ }^{-1}$ DM and
Laminaria $<10-570$ ng.g ${ }^{-1}$ DM). Porphyra from Spain and France contained the highest Se levels (Table 8).

\section{Conclusions}

The optimization and validation of the Inductively Coupled Plasma Mass Spectrometry method permits accurate and precise analysis of $\mathrm{As}, \mathrm{Cd}, \mathrm{Co}, \mathrm{Cr}, \mathrm{Mo}, \mathrm{Ni}, \mathrm{Pb}, \mathrm{Sb}, \mathrm{Se}$, and $\mathrm{V}$ in seaweeds. Applied to seaweeds destined for human consumption, this validated method could help to identify the levels of numerous toxic and bioactive elements in marine algae. In addition to helping complete Food Composition Tables, this method responds to consumer demands for stricter controls by guaranteeing the quality of seaweeds marketed for human consumption.

\section{Acknowledgements}

The present study was partially supported by the Project AGL 2005-07204-C02-02.

\section{References}

Almela, C., Algora, S., Benito, V., Devesa, V., Súñer, M.A., Vélez, D., Montoro, R., 2002. Heavy metal, total arsenic, and inorganic arsenic contents of algae food products. Journal of Agricultural and Food Chemistry 50 (4), 918-923.

Almela, C., Clemente, M.J., Vélez, D., Montoro, R., 2006. Total arsenic, inorganic arsenic, lead and cadmium contents in edible seaweed sold in Spain. Food and Chemical Toxicology 44, 1901-1908.

Bocanegra, A., Nieto, A., Blas, B., Sánchez-Muniz, F.J., 2003. Diets containing a high percentage of Nori or Konbu algae are well-accepted and efficiently utilised by growing rats but induce different degrees of histological changes in the liver and bowel. Food and Chemical Toxicology 41, 1473-1480.

Burtin, P., 2003. Nutritional Value of Seaweeds. Electronic Journal of Environmental, Agricultural and Food Chemistry 2, 1579-4377.

Caliceti, M., Argese, E., Sfriso, A., Pavoni, B., 2002. Heavy metal contamination in the seaweeds of the Venice lagoon. Chemosphere 47, 443-454.

Caroli, S., Forte, G., Lamiceli, A.L., 1999. ICP-AES and ICP-MS quantification of trace elements in the marine macro alga Fucus sample, a new candidate certified reference material. Microchemical Journal 62, 244-250.

Csikkel-Szolnoki, A., Báthori, M., Blunden, G., 2000. Determination of elements in algae by different atomic spectroscopic methods. Microchemical Journal 67, 39-42.

Davis, T.A., Volesky, B., Mucci, A., 2003. A review of the biochemistry of heavy metal biosorption by brown algae. Water Research 37, 4311-4330.

Dawczynski, C., Schäfer, U., Leiterer, M., Jahreis, G., 2007. Nutritional and toxicological importance of macro, trace, and ultra-trace elements in algae food products. Journal of Agricultural and Food Chemistry 55, 1047010475.

Domínguez-González, R., Moreda-Piñeiro, A., Bermejo-Barrera, A., Bermejo-Barrera, P., 2005. Application of ultrasound-assisted acid leaching procedures for major and trace elements determination in edible seaweed by inductively coupled plasma-optical emission spectrometry. Talanta 66, 937-942.

Farías, S., Pérez Arisnabarreta, S., Vodopivez, C., Smichowski, P., 2002. Levels of essential and potentially toxic trace metals in Antarctic macroalgae. Spectrochimica Acta B57, 2133-2140.

Farías, S., Smichowski, P., Vélez, D., Montoro, R., 2007. Total and inorganic arsenic in Antarctic macroalgae. Chemosphere 69, 1017-1024.

Galland-Irmouli, A.V., Fleurence, J., Lamghari, R., Luçon, M., Rouxel, C., Barbaroux, O. Bronowicki, J.P., Villaume, C., Guéant, J.L., 1999. Nutritional value of proteins from edible seaweed Palmaria palmata (Dulse). Journal of Nutrition Biochemistry $10,353-359$

Hardisson, A., Lozano, G., Rodríguez, M.I., Hernández, A., Bonis, A., 1996. Concentration levels of lead and cadmium in algae of the canary island littoral. Toxicology Letters 88, 80-85.

Harrington, C.F., Elahi, S., Ponnampalavanar, P., D'Silva, T.M., 1999. A protocol for the multielemental analysis of trace metal in food samples by flow injection coupled to ICP-MS. Atomic Spectroscopy 20, 174-179.

Huang, J., Hu, X., Zhang, J., Li, K., Yan, Y., Xu, X., 2006. The application of inductively coupled plasma mass spectrometry in pharmaceutical and biomedical analysis. Journal of Pharmaceutical and Biomedical Analysis 40, 227-234.

Hou, X.L., Yan, X.J., 1998. Study on the concentration and seasonal variation of inorganic elements in 35 species of marine algae. Science of the Total Environment 222, 141-156.

ICH, 1996. International Conference on Harmonization (ICH) of technical requirements for the registration of pharmaceuticals for human use. In: Validation of Analytical Procedures: Methodology, ICH-Q2B, Geneva http://www.fda.gov/ Cder/Guidance/1320fnl.pdf.

IUPAC (1997). International Union of Pure and Applied Chemistry. Compendium of Chemical Terminology, 2nd ed. Cambridge. 
Jimenez-Escrig, A., Sánchez-Muniz, F.J., 2000. Dietary fibre from edible seaweeds: chemical structure, physicochemical properties and effects on cholesterol metabolism. Nutrition Research 20, 585-589.

Le Lamer-Déchamps, S., Poucheet, P., Pérez, J.L., Bressolle, F., 2003. Validation of an inductively coupled plasma-mass spectrometry method to quantify tungsten in human plasma. Determination of percentage binding to plasma proteins. Clinica Chimica Acta 327, 39-46.

Leiterer, M., Einax, J.W., Löser, C., Vetter, A., 1997. Trace analysis of metals in plant samples with inductively coupled plasma-mass spectrometry. Fresenius Journal of Analytical Chemistry 359, 423-426.

Loban, C.S., Harrison, P.J., 1994. Seaweed ecology and physiology. Cambridge University Press, Cambridge.

Lodeiro, P., Cordero, B., Barriada, J.L., Herrero, R., Sastre de Vicente, M.E., 2005. Biosorption of cadmium by biomass of brown marine macroalgae. Bioresource Technology 96, 1796-1803.

Lozano, G., Hardisson, A., Gutierrez, A.J., Lafuente, M.A., 2003. Lead and cadmium levels in coastal benthic algae (seaweeds) of Tenerife, Canary Islands. Environment International 28, 627-631.

Mabeau, S., Fleurence, J., 1993. Seaweed in food products: biochemical and nutritional aspects. Trends in Food Science and Technology 4, 103-107.

Marinho-Soriano, E., Fonseca, P.C., Carneiro, M.A.A., Moreira, W.S.C., 2006. Seasonal variation in the chemical composition of two tropical seaweeds. Bioresource Technology 97, 2402-2406.

Moreda-Piñeiro, J., Alonso-Rodríguez, E., López-Mahia, P., Muniategui-Lorenzo, S. Prada-Rodríguez, D., Moreda-Piñeiro, A., Bermejo-Barrera, P., 2007. Development of a new sample pre-treatment procedure based on pressurized liquid extraction for the determination of metals in edible seaweed. Analytica Chimica Acta 598, 95-102.

Munilla, M.A., Gómez-Pinilla, I., Ródenas, S., Larrea, M.T., 1995. Determination of metals in seaweeds used as food by inductively coupled plasma atomic-emission spectrometry. Analusis 23, 463-466.

van Netten, C., Hoption Cann, S.A., Morley, D.R., Nettten, J.P., 2000. Elemental and radioactive analysis of commercially available seaweed. Science of the Total Environment 255, 169-175.

Nisizawa, K., Noda, H., Kikuchi, R., Watanabe, T., 1987. The main seaweed foods in Japan. Hydrobiologia 151, 5-29.

Phaneuf, D., Côté, I., Dumas, P., Ferron, L.A., LeBlanc, A., 1999. Evaluation of the contamination of Marine Algae (Seaweed) from the St. Lawrence river and likely to be consumed by humans. Environmental Research 80, 175182.

Pérez, A.A., Farías, S.S., Strobl, A.M., Pérez, L.B., López, C.M., Piñeiro, A., Roses, O., Fajardo, M.A., 2007. Levels of essential and toxic elements in Porphyra colum- bina and Ulva sp. from San Jorge Gulf, Patagonia Argentina. Science of the Total Environment 376 (1-3), 51-59.

Rao, P.V.S., Mantri, V.A., Ganesan, K., 2007. Mineral composition of edible seaweed Porphyra vietnamensis. Food Chemistry 102, 215-218.

Riekie, G.J., Williams, P.N., Raab, A., Meharg, A.A., 2006. The potential for kelp manufacture to lead to arsenic pollution of remote Scottish islands. Chemosphere $65,332-342$.

Riget, F., Johasen, P., Asmund, G., 1997. Baseline levels and natural variability of elements in three seaweeds species from West Greenland. Marine Pollution Bulletin 34, 171-176.

Rizvi, M.A., Shameel, M., 2001. Distribution of elements in marine algae of Karachi coast. Pakistan Journal of Botany 33, 357-363.

Rodushkin, I., Ruth, T., Huhtasaari, A., 1999. Comparison of two digestion methods for elemental determinations in plant material by ICP techniques. Analytica Chimica Acta 378, 191-200.

Rupérez, P., 2002. Mineral content of edible marine seaweeds. Food Chemistry 79, 23-26.

Sánchez Rodríguez, I., Huerta-Díaz, M.A., Choumiline, E., Holguín-Quiñones, O.J., Zertuche-González, A., 2001. Elemental concentrations in different species of seaweeds from Loreto Bay, Baja California Sur, Mexico: implications for the geochemical control of metals in algal tissue. Environmental Pollution 114, $145-160$.

Sharp, G.J., Samant, H.S., Vaidya, O.C., 1988. Selected metal levels of commercially valuable seaweeds adjacent to and distant from point sources of contamination in Nova Scotia and New Brunswick. Bulletin for Environmental Contamination and Toxicology 40, 724-730.

Storelli, M.M., Storelli, A., Marcotrigiano, G.O., 2001. Heavy metals in the aquatic environment of the southern Adriatic Sea, Italy. Macroalgae, sediments and benthic species. Environment International 7-8, 505-509.

Struck, B.D., Pelzer, R., Ostapczuk, P., Emons, H., Mohl, C., 1997. Statistical evaluation of ecosystem properties influencing the uptake of $\mathrm{As}, \mathrm{Cd}, \mathrm{Co}, \mathrm{Cu}, \mathrm{Hg}, \mathrm{Mn}, \mathrm{Ni}, \mathrm{Pb}$ and $\mathrm{Zn}$ in seaweed (Fucus vesiculosus) and common mussel (Myilus edulis). Science of the Total Environment 207, 29-42.

Thomsen, P., Schatzlein, D., Mercuro, D., 2003. Limits of detection in spectroscopy. Spectroscopy 18, 112-114.

Vasconcelos, M.T., Leal, F.C., 2001. Seasonal variability in the Kinetics of $\mathrm{Cu}, \mathrm{Pb}, \mathrm{Cd}$ and $\mathrm{Hg}$ accumulation by macroalgae. Marine Chemistry 74, 65-85.

Volesky, B., Holan, Z.R., 1995. Biosorption of heavy metals. Biotechnology Progress $11,235-250$.

Wang, J., Nakazato, T., Sakanishi, K., Yamada, O., Tao, H., Saito, I., 2006. Single-step microwave digestion with $\mathrm{HNO}_{3}$ alone for determination of trace elements in coal by ICP spectrometry. Talanta $68,1584-1590$. 